\title{
Coral defence against macroalgae: differential effects of mesenterial filaments on the green alga Halimeda opuntia
}

\author{
Maggy M. Nugues ${ }^{1,3, *}$, L. Delvoye ${ }^{2}$, Rolf P. M. Bak ${ }^{1,2}$ \\ ${ }^{1}$ Royal Netherlands Institute for Sea Research (NIOZ), PO Box 59, 1790 AB Den Burg, Texel, The Netherlands \\ ${ }^{2}$ University of Amsterdam, IBED, PO Box 94766, 1090 GT, Amsterdam, The Netherlands \\ ${ }^{3}$ Present address: Center for Marine Science, University of North Carolina at Wilmington, 5600 Marvin K. Moss Lane, \\ Wilmington 28409-5928, North Carolina, USA
}

\begin{abstract}
Several studies have shown that the growth of macroalgae is reduced when in contact with corals, but very few have addressed the mechanisms involved. This study provides for the first time an explicative mechanism for the inhibition of algal growth by scleractinian corals. In experimental field contacts between 8 species of scleractinian corals and the green alga Halimeda opuntia, corals extruded their mesenterial filaments (MFs) onto the plant. In some coral species, this extrusion was followed by persistent discolouration of the contacting algal segments. Microscopic examination of these segments revealed migration of chloroplasts away from the surface of segments, as well as the presence of nematocysts from the MFs fired into the algal epidermis. There was a significant relationship between the extent of algal discolouration and both the occurrence and length of the MFs, potentially explaining differences among coral species in their ability to damage algal segments. MF extrusion also occurred in experimental contacts with 2 other species of macroalgae (Lobophora variegata and Dictyota sp.). The use of extruded MFs by scleractinian corals against macroalgae is similar to their aggressive behaviour against other scleractinian coral species. However, the ranking of competitive ability against $H$. opuntia (measured by the extent of algal discolouration) differed from that established in interspecific aggressions among corals. The great abundance and wide distribution of the species of corals and macroalgae used in this study, together with observations of MFs in natural interactions, suggest that the use of MFs is a common and widespread mechanism of interaction between corals and macroalgae. We conclude that coral-algal competition involves complex mechanisms and is therefore likely to represent a complex hierarchical structure, in which macroalgae are not always able to overgrow and kill corals.
\end{abstract}

KEY WORDS: Coral-algal competition - Defence mechanisms · Algae $\cdot$ Coral Competition · Scleractinian $\cdot$ Caribbean

Resale or republication not permitted without written consent of the publisher

\section{INTRODUCTION}

Over the past 2 decades, many coral reefs in the Caribbean have experienced 'phase shifts' in which reef-building corals have been replaced by macroalgae (Carpenter 1990, Hughes 1994, Shulman \& Robertson 1996, McClanahan \& Muthiga 1998, McClanahan et al. 1999, Ostrander et al. 2000, Edmunds 2002). While there is still controversy as to what causes these changes (Hughes et al. 1999, Lapointe 1999, Miller et al. 1999, Aronson \& Precht 2000, Koop et al. 2001, Szmant 2002), competition between corals and macroalgae is considered to play a pivotal role in initiating these shifts (reviews by Miller 1998, McCook 1999). In particular, it is widely assumed that there has been a shift in the competitive environment enabling macroalgae to overgrow and kill corals. Recent studies suggest that the competitive outcome between corals 
and macroalgae could vary among particular combinations of species and that these variations could be partly due to differences in the mechanisms involved (McCook 2001, Jompa \& McCook 2002a,b, 2003a,b). However, very few studies have examined the mechanisms by which corals and macroalgae interact and our present knowledge is mostly theoretical (see review by McCook et al. 2001).

It has been shown that corals can reduce the growth of macroalgae growing in their vicinity (De Ruyter van Steveninck et al. 1988, Jompa \& McCook 2002a). However, studies of coral-algal interactions have only provided anecdotal observations of the mechanisms by which corals prevent algal colonisation or overgrowth. For instance, McCook (2001) proposed mucus secretion as the mechanism responsible for reduced growth of filamentous algal turfs in contact with the massive coral Porites lobata. De Ruyter van Steveninck et al. (1988) and Jompa \& McCook (2002a) both suggested mechanical damage by mesenterial filaments (MFs) or sweeper tentacles and allelochemicals as possible mechanisms involved in the inhibition of Lobophora variegata overgrowth of corals.

Scleractinian corals exhibit a wide variety of offensive and defensive mechanisms for acquiring or maintaining living space in the often crowded tropical reef environment. These mechanisms are likely to vary with the species or type of competitor involved due to differences in factors such as morphology and life history (Connell 1973, Wahle 1980, Grosberg 1981, Karlson 1999, McCook et al. 2001). Recently, McCook et al. (2001) proposed 7 processes by which corals could inhibit macroalgae: overgrowth, shading, abrasion, stinging, allelopathy, space pre-emption and mucus secretion. The 'stinging' mechanism includes the effect of polyps, sweeper tentacles and MFs. A number of these processes have been documented in interspecific competition among corals (reviews by Lang \& Chornesky 1990, Karlson 1999) and also between corals and a range of other animals such as zooanthids and gorgonians (Karlson 1980, Chornesky 1983, Chadwick 1987). However, none has been described for the competitive interactions between corals and macroalgae.

This paper comprises the first report of the occurrence and use of MFs by scleractinian corals against macroalgae. MFs are normally kept within the coelenteric cavities of coral polyps and serve in digestion (Yonge 1930, Muscatine 1973). However, many reef corals can extrude their filaments through the mouth cavity or the body wall onto the surface of coelenterate competitors and engage in extracoelenteric digestion of their tissue. The result is an area of bare skeleton on the subordinate competitor that can be overgrown. This process has been particularly well documented in interspecific competition among scleractinian corals (Lang \& Chornesky 1990 and references therein). Most notably, studying Jamaican corals, Lang (1973) reported on the existence of a linear hierarchy in which only the 'digestively dominant' species would attack and damage the other.

In this study, we placed colonies of several coral species next to the green alga Halimeda opuntia on a coral reef in Curaçao, Netherlands Antilles. Each experimental contact was checked for the presence of MFs and damage to the alga over a period of $8 \mathrm{~d}$. The objectives of this study were: (1) to provide a general description of this defensive mechanism against $H$. opuntia; (2) to test whether there are differences among coral species in both the use of MFs and effect on the alga; (3) to determine whether this defensive mechanism is used in contact and non-contact situations as well as against other species of macroalgae; (4) to assess the anatomical effects of MFs on $H$. opuntia through microscopic examinations of damaged and control segments.

\section{MATERIALS AND METHODS}

Study site. All experiments were carried out in the field between 4 and $20 \mathrm{~m}$ depth at Carmabi Buoy Zero, Piscaderay Bay, on the leeward south-west coast of Curaçao (6958' 26" N, 1207' 27" W; described by Bak 1977 and Van Duyl 1985). This site was chosen for its abundance of Halimeda opuntia on the reef terrace ( $5 \%$ of total projected reef area between 4 and $7 \mathrm{~m}$ depth, M. M. Nugues unpubl. data). This alga has increased in abundance in Curaçao over the last decade (R. P. M. Bak pers. obs.) and frequently interacts with living corals, utilising dead coral skeletons as a primary point of attachment and growth. It is commonly seen growing in Madracis mirabilis beds and between columns of Montastraea annularis. The brown algae Lobophora variegata and Dictyota sp. are also abundant on the reef slope, covering 26 and $4 \%$ of the total projected reef area at $20 \mathrm{~m}$ depths respectively (M. M. Nugues unpubl. data).

Experiments. Experimental interactions were induced by collecting coral colonies and placing them in direct contact with young green segments of Halimeda opuntia. This alga is very sensitive to transplantation (M. M. Nugues pers. obs.), therefore reverse transplantation was not undertaken. Adult coral colonies $(>10 \mathrm{~cm}$ in diameter) preferentially loosely attached to the substratum, but showing no sign of damage or stress (e.g. disease, bleaching, predation, algal overgrowth or mucus secretion) were selected. Colonies were placed a few cm away from the selected segments for $24 \mathrm{~h}$ before contacts were initiated. At the start of the 
experiment, each coral colony was placed in direct and continuous contact with the tips of 1 to 3 alga segments without distorting or bending the plant. Contact was made so that competitors touched when both coral polyps and tissues were contracted. Care was taken to ensure that no damage to the living coral tissue was made during the transplantations.

We used 8 species of scleractinian corals (see Fig. 3 legend). Dead rocks were placed in contact with Halimeda opuntia to serve as controls for damage to the algae not associated with experimental contact with live coral colonies. As this study was not designed to examine the effects of macroalgae on corals, no control for damage to the coral was established.

Interactions were examined at the start of the experiment and after 1 and $6 \mathrm{~h}$, and 1, 2 and $8 \mathrm{~d}$; most were observed during the first night (approx. $10 \mathrm{~h}$ after contact) and some were examined for $3 \mathrm{wk}$. During each observation, data were collected on occurrence of MF extrusion, maximal length of extruded filaments, signs and extent of damage to both competitors, and the presence of other organisms. Several MFs are often extruded at once; they can be highly convoluted and retract within a few minutes when disturbed (see Fig. 1A-E). We estimated the length of an MF as the straight-line distance from the site of extrusion on the polyp surface to the tip of the filament. The 'maximal length of extruded filaments' was the length of the longest filament. Algal damage by MFs was always in the form of tissue discolouration (see Figs. 1A \& 2C). We measured the 'extent of algal discolouration' as the length of discoloured tissue along the branch axis. If several branches were in contact with the coral colony (e.g. see Fig. 2), the extent of algal discolouration was measured along the most damaged branch. All measurements were recorded to the nearest $\mathrm{mm}$ using calipers without touching any MFs or interfering with the interaction.

Unexpected factors sometimes affected the interactions. In a few cases, competitors changed position (possibly due to wave action or other disturbances), and 3 pairings between Montastraea annularis and Halimeda opuntia were disturbed by the xanthid crab Domecia acanthophora. The crabs were usually found on the coral tissue next to the algal segments. The invasion by $D$. acanthophora was always associated with tissue damage to the coral, and stopped, and sometimes even reversed, the algal discolouration process. When any such disturbance was noticed during our observations, pairings were discarded. At the end of the experiment, at least 5 replicate interactions were surveyed for each coral species and for the control (see Fig. 3 for exact sample sizes).

In addition to the main experiment, a small series of experiments were conducted to explore the specificity of MF extrusion. First, specimens of Montastraea cavernosa and $M$. annularis were placed at different distances from Halimeda opuntia to try to simulate the initial contact between competitors in natural interactions. Distances between segments and (contracted) corals were $0.5,1$ and $2 \mathrm{~cm}$ for $M$. cavernosa and 0.25 , 0.5 and $1 \mathrm{~cm}$ for $M$. annularis. Second, to determine whether this mechanism was used against other macroalgae and inanimate subjects, colonies of $M$. cavernosa and Colpophyllia natans were placed in direct contact with 2 other species of macroalgae, Lobophora variegata and Dictyota sp., and with clothes pegs. In this experiment, plants and clothes pegs were transplanted next to the coral colonies. We collected dead coral rocks covered with $L$. variegata or Dictyota sp. (e.g. dead plates of Agaricia lamarckii) and transplanted them next to coral colonies, ensuring that only algal blades were in contact with the coral tissue. Transplants were placed in areas where $L$. variegata or Dictyota sp. was naturally present (but not interacting with the selected colonies). Such transplants have been used in long-term ( 1 yr) experiments without negative effects to the plants other than those due to the effects of corals (M. M. Nugues pers. obs.). In both experiments, 2 to 3 pairs were surveyed for each treatment.

All experimental contacts were conducted between November and December 2002. Experiments with Halimeda opuntia, Dictyota sp. and Lobophora variegata were conducted at 5, 15 and $20 \mathrm{~m}( \pm 1)$ depths respectively. All coral colonies were collected at the depth where interactions were initiated to minimise stress to the colonies. Experiments were completed by field observations of natural interactions between corals and $H$. opuntia conducted between July and December 2002.

Anatomical observations. Samples of Halimeda opuntia were collected by carefully breaking off the plant at a node, leaving several healthy segments between it and the area we wanted to observe microscopically. They were immediately preserved in situ by putting them into small zip-lock bags and injecting a small dose of $37 \%$ formaldehyde with a syringe before sealing. In the laboratory, the samples were stored in a solution of formaldehyde in seawater (end concentration $4 \%$ ). Selected segments were decalcified in $4 \%$ L-ascorbic acid with a few drops of formaldehyde to prevent bacterial and fungal growth. The solution was replaced every $24 \mathrm{~h}$ for a period of $6 \mathrm{~d}$ prior to microscopy. Examination was carried out under a Leitz Ortholux microscope and microphotographs were taken with an Orthomat camera. We examined 3 types of samples: (1) and (2) non-competing segments collected during daytime and nighttime respectively; (3) discoloured segments that had been in direct contact with Montastraea cavernosa for a period of $8 \mathrm{~d}$. 
Statistical analyses. Data were not normally distributed and did not show homogenous variance even after transformation; thus ANOVA was not performed. Differences among coral species in the occurrence of MFs were analysed using an heterogeneity G-test, followed by a simultaneous test procedure (STP) to determine homogeneous groups (Sokal \& Rohlf 1995). Other variables were analysed using the KruskalWallis test, followed by post-hoc comparisons using
Mann-Whitney $U$-tests where appropriate. In order to compromise between a large overall Type I error (which would arise at an $\alpha$ of 0.05 for each separate test) and a large overall Type II error (which would arise with a strict application of Bonferroni correction, i.e. at an $\alpha$ of $0.05 / 36=0.00139$ ), we used an $\alpha$ of 0.005 in each separate test. Spearman rank-order correlation analyses (SPSS) were conducted to examine relationships between the different variables.
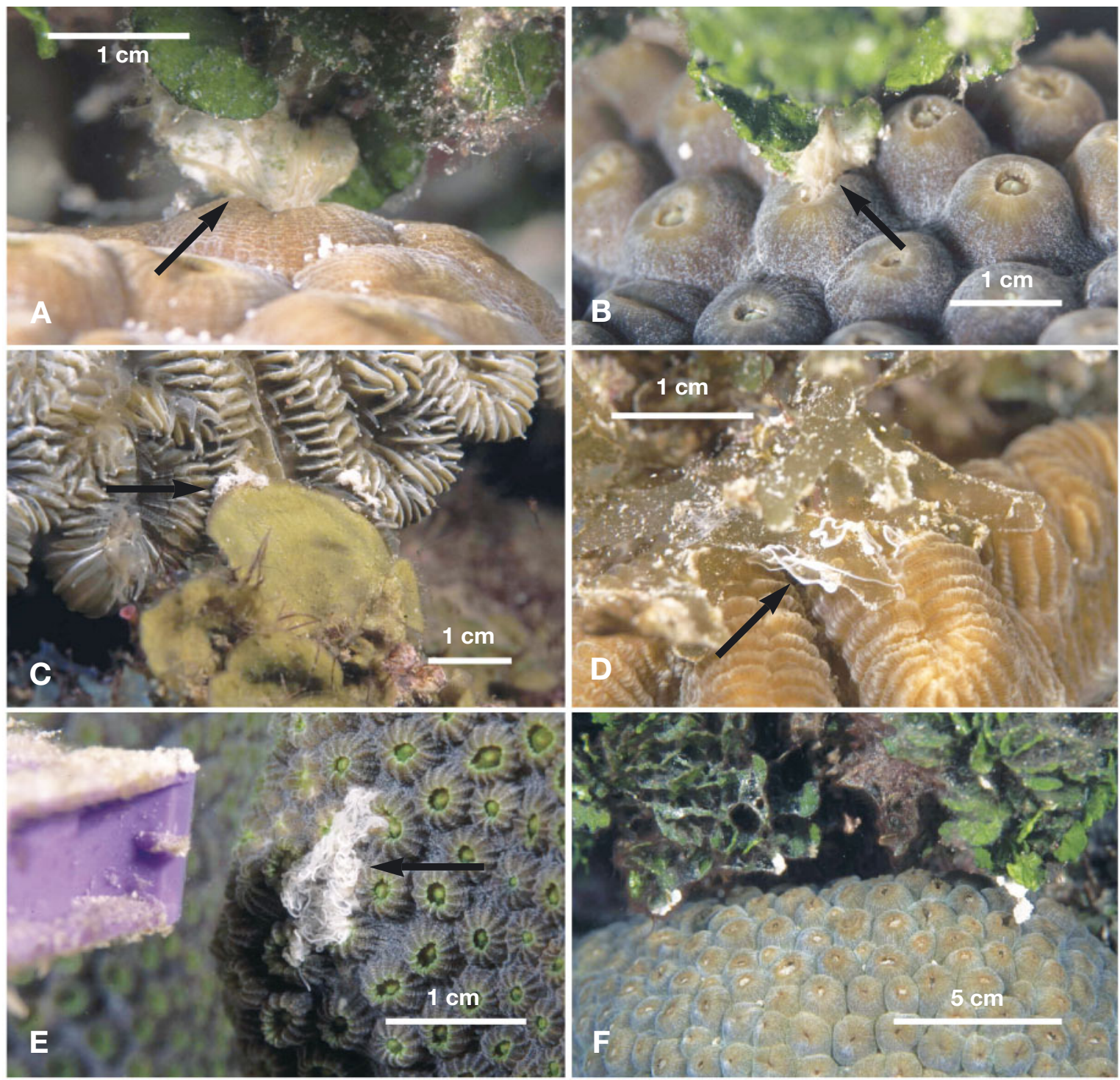

Fig. 1. Mesenterial filaments (MFs; black arrows) of corals extruded over/towards algae. (A,B) MFs of transplanted Montastraea cavernosa extruded over segments of Halimeda opuntia after $1 \mathrm{~h}$ contact during daytime; in (A), segment discolouration is clearly visible under extruded MFs of M. cavernosa. (C) MFs of Meandrina meandrites extruded towards transplanted Lobophora variegata blade during first night (approx. $10 \mathrm{~h}$ ) after initial of contact; filaments are not spread over surface of alga and no damage to alga is visible. (D) MFs of Colpophyllia natans extruded over transplanted Dictyota sp. $24 \mathrm{~h}$ after initial contact during daytime; no damage to alga is visible. (E) Extruded MFs of $M$. annularis $24 \mathrm{~h}$ after initial contact with transplanted clothes peg (peg was in direct contact with the coral but was moved for the photograph); filaments did not adhere to the clothes peg during this process (M. M. Nugues pers. obs.). (F) H. opuntia growing beside M. cavernosa colony at $5 \mathrm{~m}$ depth in natural (unmanipulated) conditions; discoloured segments of $H$. opuntia can be seen in proximity to colony; segments are not in direct physical contact with coral tissue; no MF is visible. All photographs taken at Carmabi Buoy Zero (695 $\left.58^{\prime} 26^{\prime \prime} \mathrm{N}, 12^{\circ} 07^{\prime} 27^{\prime \prime} \mathrm{W}\right)$ 


\section{RESULTS}

\section{General observations}

Coral polyps generally extruded their filaments within a few hours after initial contact with Halimeda opuntia. In Montastraea cavernosa, the extrusion sometimes started after as little as 15 min and consisted of a large mass of highly convoluted filaments (Fig. 1A,B). The filaments appeared at the mouth or through a break in the body wall close to the point of contact and spread over the contacting algal segment(s). In some cases, filaments were long enough to spread over the next segment on the same branch. The MFs were highly extensible. When the interacting segment and the coral were moved apart, the filaments stretched and adhered to the surface of the segment(s), but then slowly withdrew into the coelenteron. The surface area of the plant covered by filaments became discoloured within a few minutes of extrusion. Within a few hours, the filaments had withdrawn into the coelenteron, leaving 1 or more discoloured segments behind. In some interactions, MFs were observed intermittently, suggesting that this process may have been repeated several times over the $8 \mathrm{~d}$ period. A typical series of events during an experimental contact between $H$. opuntia and $M$. cavernosa is depicted in Fig. 2.

Extruded MFs were more frequently observed during the first night than during any daytime period: $37 \%$ of coral colonies had extruded MFs on the first night (approximately $10 \mathrm{~h}$ after contact) compared to 20 and $10 \%$ after 6 and $24 \mathrm{~h}$ of contact respectively ( $\mathrm{n}=30$ colonies, coral species pooled). Corals showed no deleterious effect of direct contact with Halimeda opuntia over the $8 \mathrm{~d}$ period, except when the interaction was disturbed by the xanthid crab Domecia acanthophora (see 'Materials and methods'). Sweeper tentacles were never observed during the experiment, even in transplants surveyed over a 3 wk period.

\section{Differences among coral species}

The extrusion of MFs was observed in all coral species except Porites astreoides and Madracis mirabilis (Fig. 3A), although MFs are present in both these latter species. Short (1 mm length) MFs were seen in $M$. mirabilis during preliminary experiments with Halimeda opuntia (M. M. Nugues pers. obs.), and
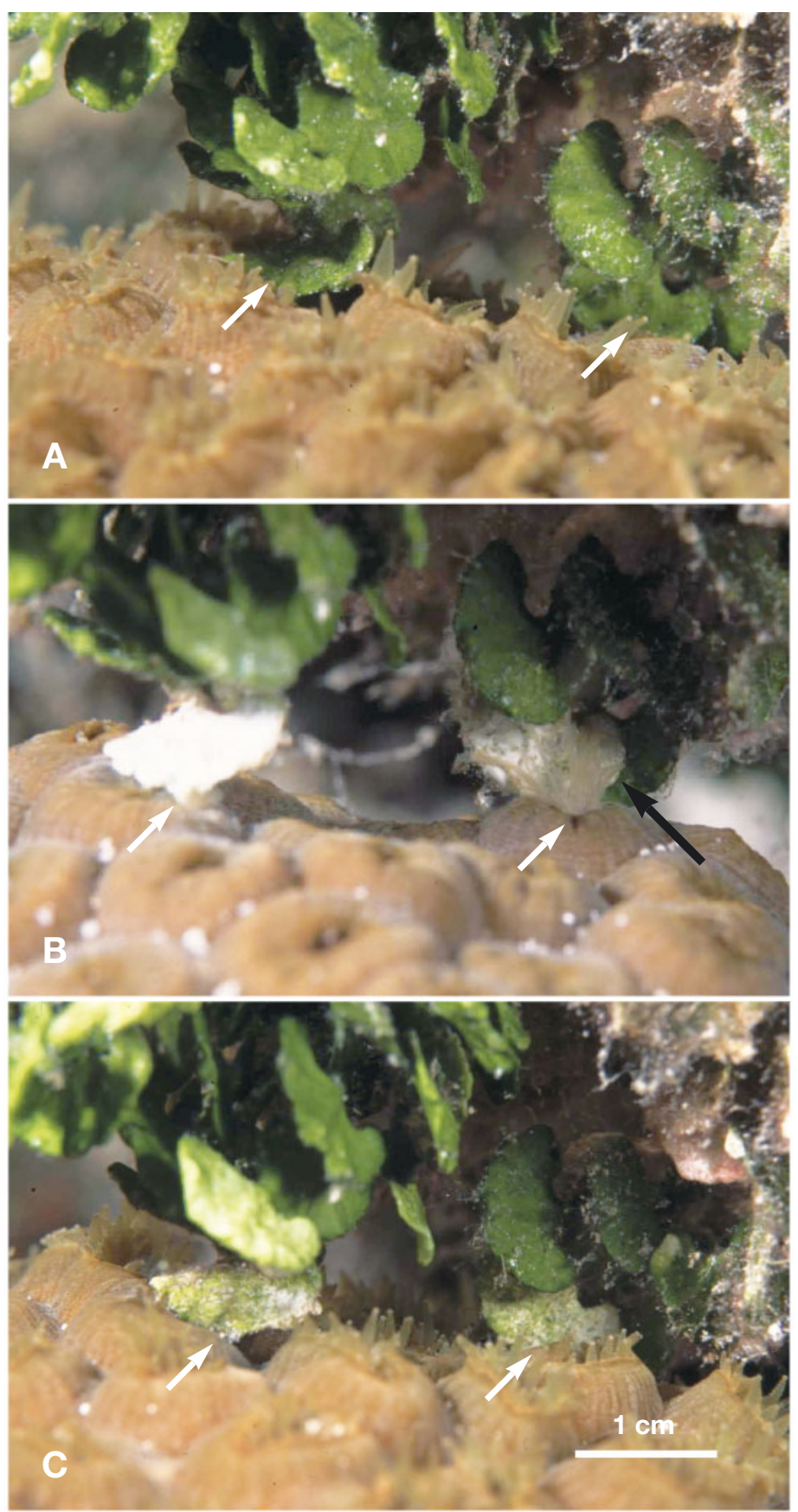

Fig. 2. Montastraea cavernosa and Halimeda opuntia. In situ timeseries photographs of experimental contact at (A) start of experiment, 2 segments of $H$. opuntia are in contact with coral tissue (white arrows), (B) after $1 \mathrm{~h}$, both segments are discoloured, right segment is visibly covered by MFs (black arrow); (C) after 6 h, MFs have withdrawn into coelenteron, the 2 segments remain discoloured, green patches are visible on segments. All photographs taken during daytime at Carmabi Buoy Zero

we suspect that they are too small to be visible with the naked eye. The percentage occurrence of MFs varied significantly among coral species (heterogeneity $G$-test, $\left.G_{H}=39.58, \mathrm{df}=7, \mathrm{p}<0.001\right)$. Values ranged 

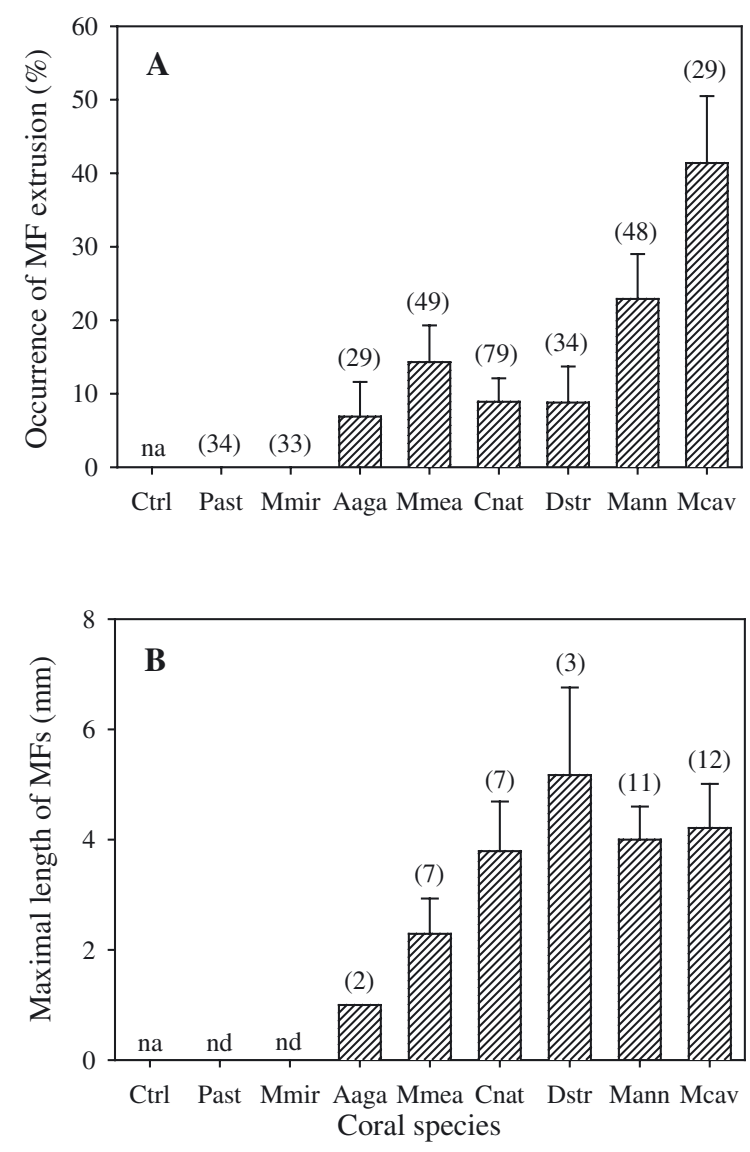

from $0 \%$ for $P$. astreoides and $M$. mirabilis to $41 \%$ for Montastraea cavernosa (Fig. 3A). STP tests showed that 2 species groups (Past, Mmir, Aaga, Mmea, Cnat, Dstr and Mmea, Dstr, Mann, Mcav) formed homogeneous sets (abbreviations as in Fig. 3). The maximal length of MFs varied more than 5-fold among species, with $M$. cavernosa, M. annularis and Diploria strigosa showing the highest values (Fig. 3B). However, differences among species were not significant (KruskalWallis test, $H=7.4, \mathrm{df}=5, \mathrm{p}=0.19$ ).

At the end of the $8 \mathrm{~d}$ period, the extent of algal discolouration differed significantly among coral species (Fig. 3C, Table 1). Halimeda opuntia segments in contact with Montastraea cavernosa and $M$. annularis had an average discolouration extent of $13.6 \mathrm{~mm}( \pm 1.0 \mathrm{SE})$ and $5.4 \mathrm{~mm}( \pm 0.4 \mathrm{SE})$ respectively and were significantly more discoloured than segments in contact with all other coral species, except Diploria strigosa for M. annularis (Table 1). In comparison, segments in contact with Porites astreoides and Madracis mirabilis showed very little discolouration and damage was never observed on plants in contact with

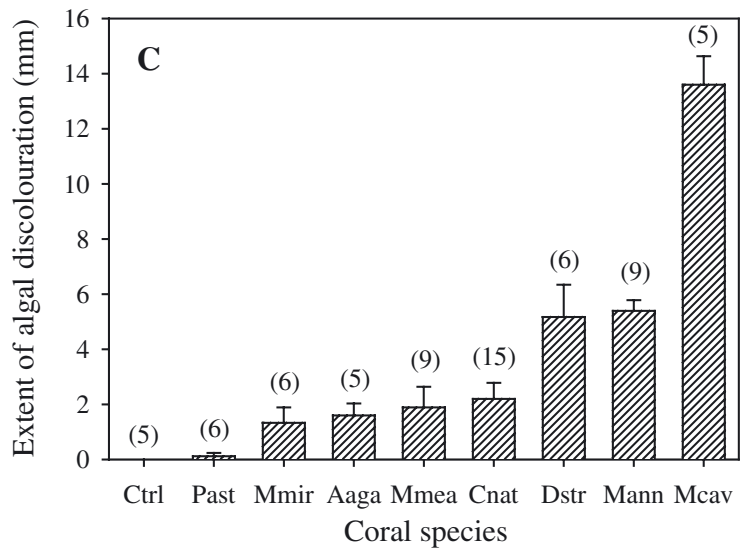

Fig. 3. Effects of coral MFs on Halimeda opuntia. Values are means $( \pm 1 \mathrm{SE})$ for each coral species and control during experimental contact. Coral species ranked according to extent of algal discolouration after $8 \mathrm{~d}$ of contact. For (A) and (B), each observation was considered independent regardless of whether or not it was made on the same colony, since extrusion of MFs occurred sporadically. (A) MF occurrence; (n) number of experimental contacts multiplied by number of observations for each (some contacts were not observed on first night). (B) MF maximal length; (n) number of MF extrusions. (C) Extent of

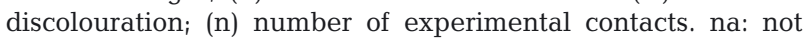
available (no coral competitor involved); nd: not determined (extrusion of MFs did not occur during observations); Ctrl: control; Aaga: Agaricia agaricites; Cnat: Colpophyllia natans; Dstr: Diploria strigosa; Mann: Montastraea annularis; Mcav: Montastraea cavernosa; Mmea: Meandrina meandrites; Mmir: Madracis mirabilis; Past: Porites astreoides

dead coral rocks (controls). The extent of algal discolouration was positively correlated with both the occurrence of MFs and the length of extruded MFs, supporting a causal link between MFs and algal damage (Fig. 4).

As a function of time (Fig. 5), segments became discoloured after $1 \mathrm{~h}$ but generally regained some colour after $6 \mathrm{~h}$ (see also Fig. 2). When physically touched, Halimeda opuntia can go pale within minutes (M. M. Nugues pers. obs.), which could explain these peaks. They were

Table 1. Halimeda opuntia. Results of post-hoc multiple comparisons (pairwise comparisons and mean ranks; Mann-Whitney $U$-test) of extent of segment discolouration caused by different coral species. Kruskal-Wallis test showed significant differences among species (chi-square $=40.16$; df $=8 ; p<0.01$ ). Species abbreviations as in legend to Fig. $3 .{ }^{*} \mathrm{p}<0.005$; ns: not significant

\begin{tabular}{|lccccccccc|}
\hline & Ctrl & Past & Mmir & Mmea & Aaga & Cnat & Dstr & Mann & Mcav \\
\hline Ctrl & 10.50 & & & & & & & & \\
Past & ns & 12.42 & & & & & & & \\
Mmir & ns & ns & 25.83 & & & & & & \\
Mmea & ns & ns & ns & 28.11 & & & & & \\
Aaga & $*$ & $*$ & ns & ns & 31.00 & & & & \\
Cnat & ns & ns & ns & ns & ns & 31.13 & & & \\
Dstr & ns & ns & ns & ns & ns & ns & 46.92 & & \\
Mann & $*$ & $*^{*}$ & $*$ & $*$ & $*^{*}$ & $*^{*}$ & ns & 50.28 & \\
Mcav & $*$ & $*$ & $*$ & $*$ & $*^{*}$ & $*^{*}$ & & $*$ & 64.00 \\
\hline
\end{tabular}


observed in most coral species, including Porites astreoides and Madracis mirabilis, but not in Montastraea cavernosa, possibly because the latter was able to affect the plants very rapidly. Nevertheless, discolouration increased greatly with time in $M$. cavernosa, $M$. annularis and Diploria strigosa. After $2 \mathrm{~d}$, values showed a trend to stabilise and were not very different from those observed after $8 \mathrm{~d}$. Some transplants were surveyed over a $3 \mathrm{wk}$ period, but no further change in the extent of segment discolouration was noticed. These observations indicate that our study period was adequate to describe the shortterm (weeks to months) outcome of experimental contacts between corals and $H$. opuntia.

\section{Specificity of MF extrusion}

Extruded filaments were observed in Montastraea cavernosa colonies positioned $0.5 \mathrm{~cm}$ away from algal segments, but not 1 and $2 \mathrm{~cm}$ away. However, discolourations were observed on segments $1 \mathrm{~cm}$ away
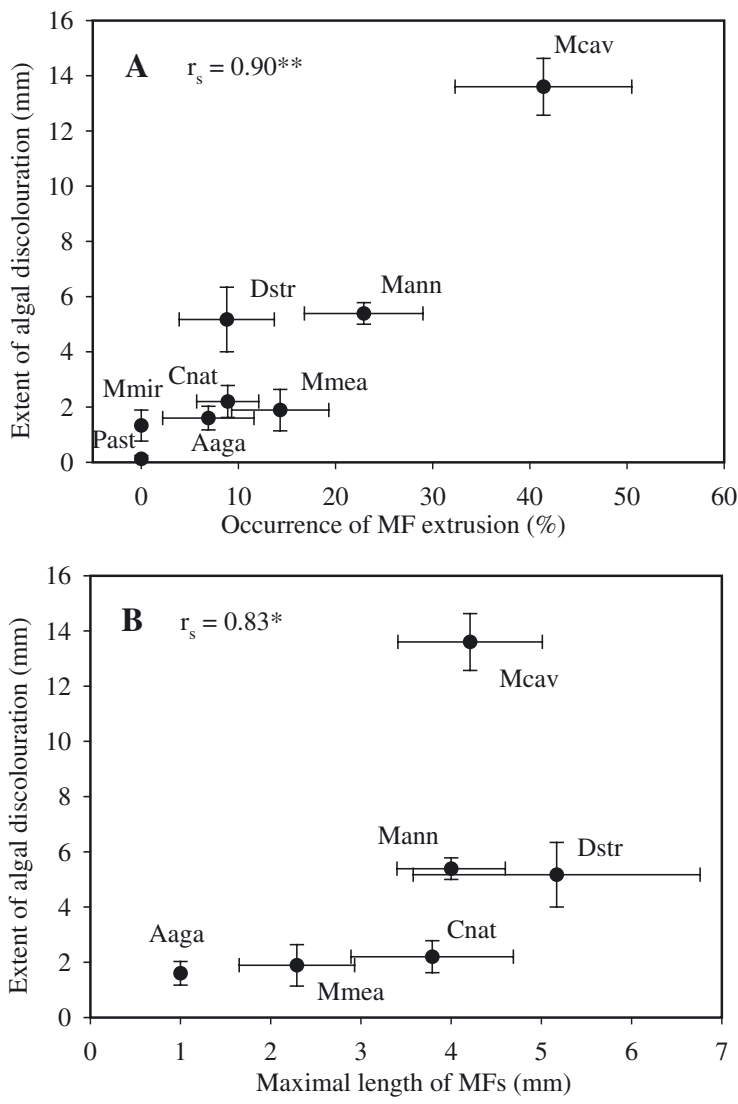

Fig. 4. Halimeda opuntia. Extent (means $\pm 1 \mathrm{SE}$ ) of algal discolouration caused by each coral species after $8 \mathrm{~d}$ of experimental contact as a function of (A) percentage occurrence of MFs, and (B) maximal length of extruded MFs (Fig. 3). Species abbreviations and $n$ values as in Fig. 3. $r_{s}$ : Spearman's rank-order correlation coefficient; ${ }^{*} \mathrm{p}<0.05,{ }^{* *} \mathrm{p}<0.01$ from the living coral tissue, suggesting that MFs had been extended this distance. In contrast, extruded filaments were not observed on $M$. annularis colonies $0.25 \mathrm{~cm}$ or more away from algal segments and no algal damage was noticed.

Contacts with Lobophora variegata and Dictyota sp. triggered the extrusion of MFs in both Montastraea cavernosa and Colpophyllia natans (Fig. 1C,D). Unlike Halimeda opuntia, these algae did not show obvious damage after contact with MFs. However, no specimen was collected for detailed microscopic examination.
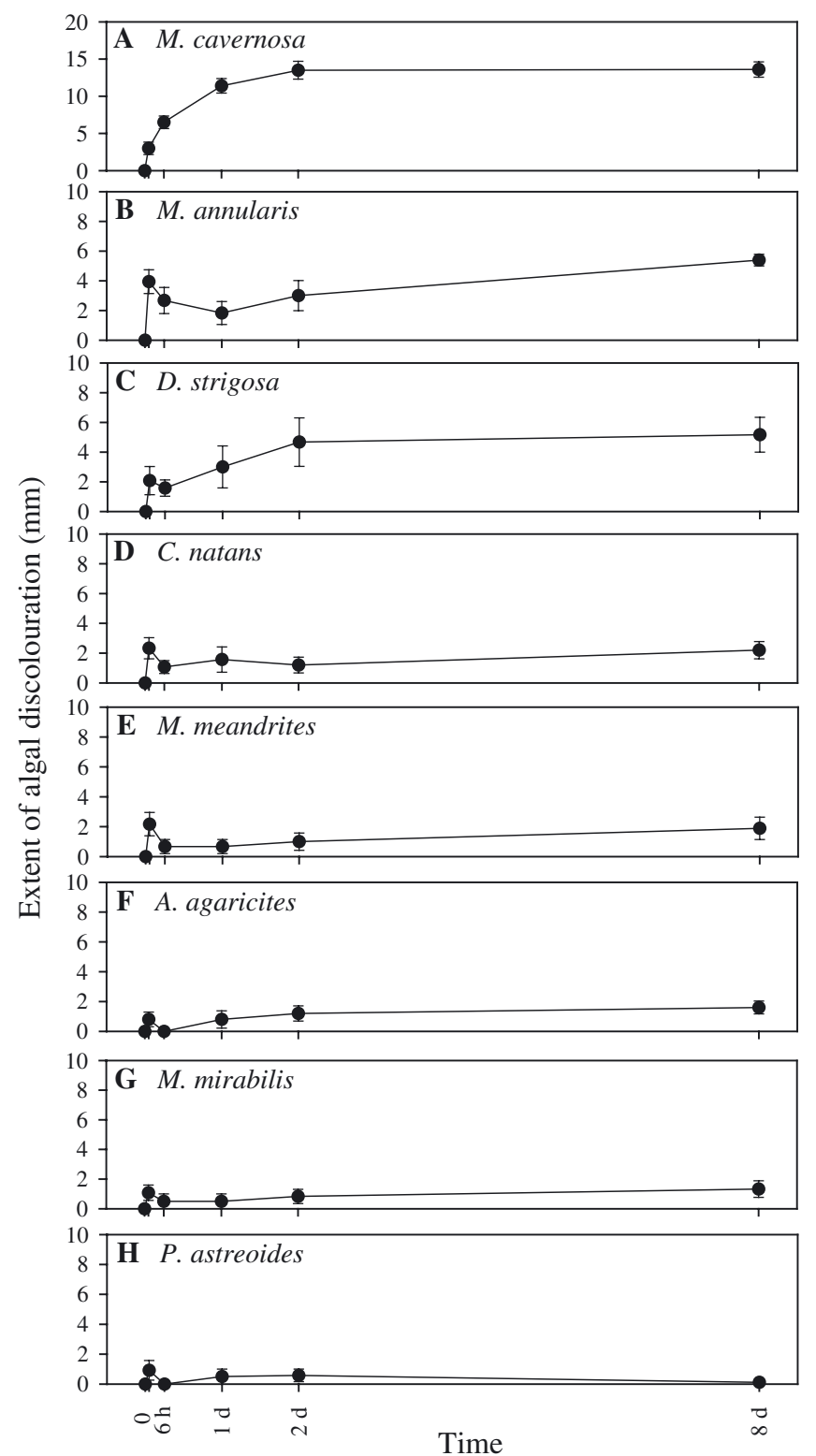

Fig. 5. Halimeda opuntia. Extent (means $\pm 1 \mathrm{SE}$ ) of algal discolouration as a function of time for each coral species during experimental contact with alga. Second observation (not labelled on abscissa) was made $1 \mathrm{~h}$ after contact. For full specific names see legend to Fig. 3 ; $\mathrm{n}$ values as in Fig. 3C 
Moreover, the filaments did not spread over L. variegata blades but only gathered on their edges (Fig. 1C). Contacts with a plastic clothes peg also caused extrusion of MFs (Fig. 1E), suggesting that this mechanism can be induced by simple mechanical pressure on the coral tissue.

\section{Anatomical observations of Halimeda opuntia}

Microscopic examination of surfaces and crosssections of control and damaged segments showed a clear change in the distribution pattern of chloroplasts in damaged segments. In daytime control segments, chloroplasts were tightly packed in the primary utricles, with only a few chloroplasts in the secondary utricles (Fig. 6A,B). In contrast, in daytime damaged segments, the chloroplasts had moved out of the primary utricles and were gathered into the secondary utricles towards the center of the segments (Fig. 6C,D). There was no sign of breakdown of photosynthetic products in the primary utricles, supporting the conclusion that the chloroplasts had moved out instead of being

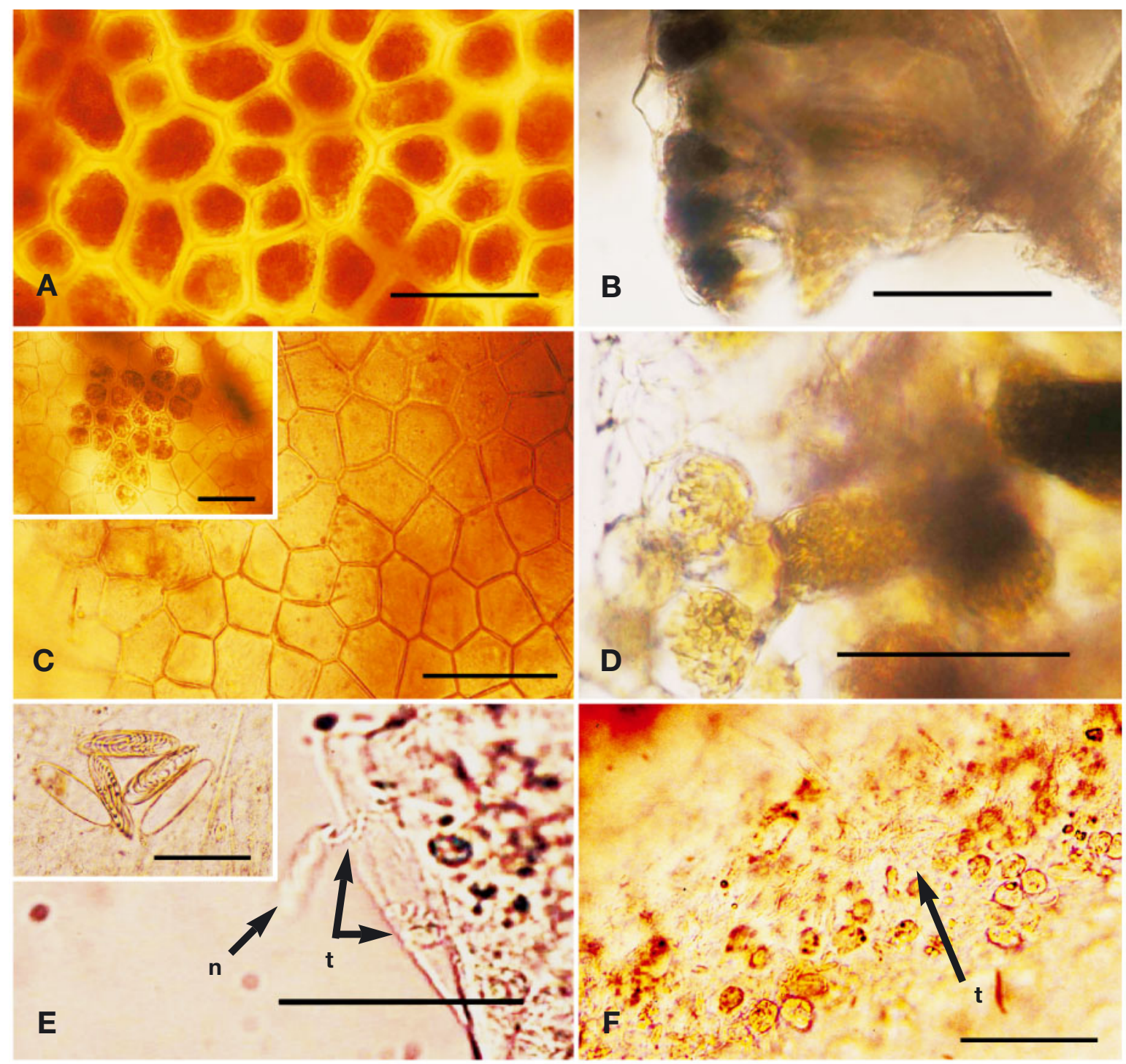

Fig. 6. Halimeda opuntia. Microphotographs of control and damaged segments of alga preserved in situ in formaldehyde during daytime. Damaged segments were placed in direct contact with Montastraea cavernosa for $8 \mathrm{~d}$ prior to sampling. Control segments were free-standing segments. (A) Surface view of control segments showing primary utricles. (B) Cross-section of control segments showing primary and secondary utricles. (C) Surface view of damaged segments showing primary utricles; inset: aggregations of primary utricles containing chloroplasts occasionally found on damaged segments. (D) Cross-section of damaged segments showing primary and secondary utricles. (E) Nematocyst threads (t) and nematocyst (n) from M. cavernosa MF fired into alga epidermis; inset: nematocysts observed during preparation of damaged segments; 2 are discharged. (F) Nematocysts threads (t) forming tangled web in alga epidermis. Scale bars $=50 \mu \mathrm{m}$ 
destroyed. Occasionally we found aggregations of primary utricles still packed with chloroplasts (Fig. 6C: inset). This distribution pattern was similar to that observed in night-time control segments (in which chloroplasts also moved out of the primary utricles), but no aggregation was found in surfaces of night-time control segments.

In addition, nematocysts from Montastraea cavernosa MFs were found in daytime damaged segments, with some having discharged their coiled thread into the alga epidermis (Fig. 6E). Numerous threads from nematocysts were observed entangled in the epidermis of damaged segments (Fig. 6F). Taken together, these observations demonstrate that the discolouration of Halimeda opuntia segments in contact with corals is due to the movement of chloroplasts away from the periphery of the segments. This migration of chloroplasts could be the result of the action of MFs that, once extruded over the segments, fire nematocysts into the alga epidermis.

\section{Field observations}

Field observations suggest that corals commonly use this mechanism to damage macroalgae. We observed polyps of several coral species extruding filaments onto Halimeda opuntia segments. These segments were often discoloured. We also found bleached segments of $H$. opuntia in contact and non-contact interactions with corals, particularly Montastraea annularis and $M$. cavernosa (Fig. 1F). Although we could not establish that the bleaching was due to the extrusion of MFs, the damage was localised to the segment(s) closest to the neighbouring coral and was very similar to that observed in our transplant experiments.

\section{DISCUSSION}

The results of this study provide strong support that MF extrusion can serve as a coral defence mechanism against macroalgae. In transplants with Halimeda opuntia and 2 other species of macroalgae (Lobophora variegata and Dictyota sp.), corals readily extruded MFs onto the plants. This extrusion was associated with a persistent discolouration of $H$. opuntia segments. Microscopic examinations of these segments indicated that this was caused by the inward migration of chloroplasts away from the segment surface. Several results suggest that MFs initiated these changes: (1) the sequence of these events, i.e. the extrusion of filaments over $H$. opuntia segments was rapidly followed by signs of discolouration; (2) there was a positive correlation between the extent of segment dis- colouration and both the occurrence and length of MFs; (3) discharged nematocysts from MFs were present on the epidermis of affected segments. This last point further suggests a mechanism by which MFs could have initiated the withdrawal of chloroplasts. Nematocysts are known to contain cytotoxic molecules that can be injected into their prey upon firing (Van-Praet 1985, Burnett et al. 1995). MFs also contain gland cells that secrete proteolytic enzymes (VanPraet 1985). At this stage, it is unclear which of these physiological effects triggered the movement of chloroplasts but it is likely that the plants withdrew their chloroplasts as a response to toxins discharged by nematocysts.

This study provides a mechanism that could explain the inhibition of algal growth close to coral margins found in earlier studies (De Ruyter van Steveninck et al. 1988, Jompa \& McCook 2002a). The movement of chloroplasts away from the periphery of segments is a process normally observed at night in Halimeda sp. (Drew \& Abel 1990). Such migration has been associated with reduced photosynthetic and calcification rates in this alga (Stark et al. 1969, Borowitzka \& Larkum 1976, Drew \& Abel 1990). In our experiments, affected segments of $H$. opuntia remained continuously discoloured for at least $3 \mathrm{wk}$ (maximum observation time), indicating an important energy loss for the plant. No effect was visible on Lobophora variegata or Dictyota sp. blades in contact with corals during this study. However, blades from both species in contact with corals showed signs of damage in the form of notched and frayed margins in the field (De Ruyter van Steveninck et al. 1988, M. M. Nugues unpubl. data), thus suggesting that corals can also affect these macroalgae.

Scleractinian corals extrude MFs to digest large prey items (Yonge 1930, Muscatine 1973) and attack other anthozoan species (Chadwick 1987, Lang \& Chornesky 1990 and references therein). This study comprises the first report of corals extruding MFs over macroalgae. The extrusion response observed is very similar to that reported as being used against other scleractinian corals (reviewed by Lang \& Chornesky 1990). Lang (1973) found that Jamaican corals extruded their filaments 0.5 to $12 \mathrm{~h}$ after initiation of contact with certain coral species. In this study, extrusion sometimes started after as little as $15 \mathrm{~min}$, and the timing of algal discolouration suggests that the attack occurred within $12 \mathrm{~h}$ (Fig. 5). Also, similar to the results of Lang (1973), the attacks were more prevalent at night, presumably as a result of nocturnal expansion of the coral tissues. The distance separating corals and algae affected the readiness to extrude MFs. This has been also shown in interspecific interactions among corals (Chornesky 1983). In this study, Montastraea cavernosa was able to 
damage plants up to $1 \mathrm{~cm}$ away from its contracted tissue, whereas $M$. annularis was unable to do so only $0.25 \mathrm{~cm}$ away. We suspect that species-specific differences in tissue and polyp expansion influence the distance at which coral species MFs can affect macroalgae.

The factors initiating the use of MFs have not been studied thoroughly. However, the relationship between coral tissue expansion and the distance at which corals affect macroalgae, plus the fact that corals extrude MFs following contact with a clothes peg, together suggest that tactile contact is involved in initiating the process. Corals have been found to extrude their filaments when exposed to stressful situations in several studies, e.g. when oil is introduced into their coelenteron (Bak \& Elgershuizen 1976), when they are handled roughly (Duerden 1902), kept in suboptimal laboratory conditions (Price 1973), or exposed to continuous silting of sand (Riegl 1995). The corallimorpharian Corynactis californica was observed to use filaments when accidentally crushed or desiccated (Chadwick 1987).

Disturbance by the xanthid crab Domecia acanthophora prevented corals from damaging the alga and presumably extruding MFs. Xanthid crabs and other reef organisms have been found to interfere with competitive interactions among corals (Bak et al. 1982, Chornesky 1983, review by Lang \& Chornesky 1990). The segments of Halimeda opuntia in contact with corals seemed to create a suitable microhabitat in which the crabs can feed on adjacent coral tissue. Of 15 interactions, $3(20 \%)$ between Montastraea annularis and $H$. opuntia were disturbed by $D$. acanthophora. This crab was rarely found in interactions with other coral species (only 1 was found in an experimental interaction between $H$. opuntia and Diplorea strigosa during preliminary work, M. M. Nugues pers obs). However, these observations indicate that interference by epifauna could be a significant factor in coral-algal competition.

Nevertheless, the results of the present study differ in at least 2 ways from those found in studies on interspecific competition among corals. First, Lang (1973) established a hierarchy of Jamaican corals by ranking species according to the number of subordinate species being injured when placed in direct contact. Lang's work was based on short-term experiments $(<8 \mathrm{~d})$, and is thus comparable with our experiments. We ranked our coral species based on the extent of algal discolouration and compared this ranking with Lang's hierarchy (Fig. 7). Porites astreoides, Madracis mirabilis and Agaricia agaricites ranked low in both studies but the overall relationship was not significant. Lang (1973) found that meandrinid corals were dominant over faviid corals, whereas in our study Meand-

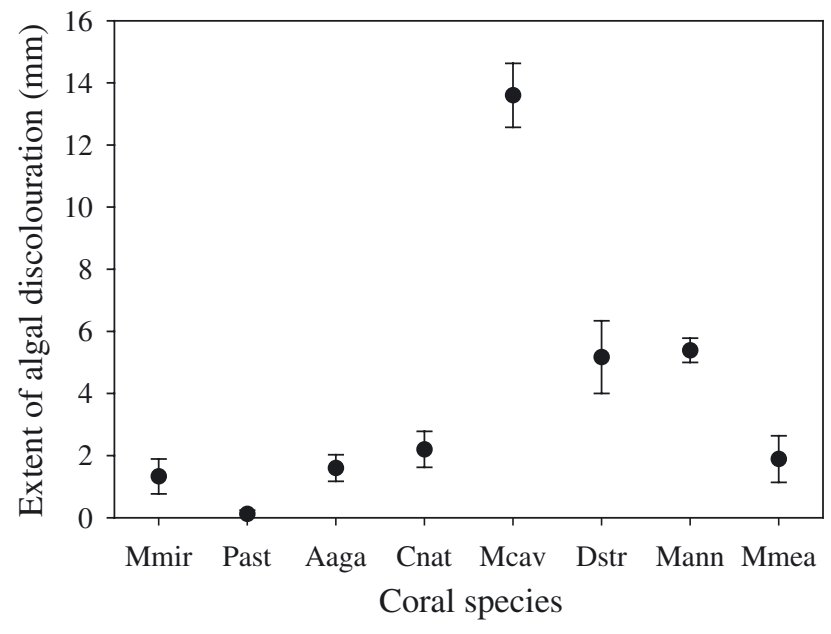

Fig. 7. Halimeda opuntia. Extent (means \pm 1 SE) of algal discolouration caused by each coral species after $8 \mathrm{~d}$ of experimental contact. Coral species ranked according to hierarchy of extracoelenteric digestion of Lang (1973), with weakest competitor on left and strongest on right. Abbreviations as in legend to Fig. 3, $n$ values as in Fig. 3C

rina meandrites caused significantly less plant damage than Montastraea cavernosa and M. annularis (Table 1). Similarly, also in Jamaica, Richardson et al. (1979) found that, when M. cavernosa and M. annularis were placed in contact, the latter extruded MFs over the former. In our study, M. cavernosa caused significantly more plant damage than $M$. annularis (Table 1). While we need to be cautious when comparing these studies, it is clear that coral species that are highly ranked in coral-coral interactions are not necessarily the species most damaging to macroalgae.

Secondly, several coral species studied here, i.e. Madracis mirabilis, Montastraea cavernosa and A. agaricites, have been reported to use sweeper tentacles against other corals (Den Hartog 1977, Richardson et al. 1979, Bak et al. 1982, Chornesky 1983, Logan 1984). These tentacles can be formed 1 wk following initiation of contact (Bak et al. 1982). Therefore, they could have been observed in this study in the transplants surveyed over a $3 \mathrm{wk}$ period. However, these tentacles were never seen during our experimental and field observations. This supports the results of Chornesky (1983), who demonstrated that sweeper tentacles were used specifically following tissue contact with anthozoan competitors. McCook et al. (2001) listed sweeper tentacles as a possible mechanism of coral inhibition by algae. However, we suggest that sweeper tentacles are specific to competition among anthozoans and cannot serve as a mechanism of interaction between corals and macroalgae.

The use and importance of MFs in coral-algal competition remain to be studied for more combinations of coral and algae species. For instance, corals may be 
less likely to extrude MFs against tall, bushy macroalgae, such as Sargassum spp., which can cause polyp retraction via abrasion (River \& Edmunds 2001). However, the importance of MFs in spatial competition between corals and macroalgae is suggested by the numerous observations of this mechanism and its impact on Halimeda opuntia in natural conditions. The 3 macroalgae used in this study are widespread and common species worldwide, especially on degraded reefs (Diaz-Pulido \& Diaz 1997, McClanahan et al. 1999, Littler \& Littler 2000, Williams \& Polunin 2001, Edmunds 2002). They have been observed overgrowing scleractinian corals at sites in the Caribbean (De Ruyter van Steveninck et al. 1988, Hughes 1994, McClanahan et al. 1999, Littler \& Littler 2000) and elsewhere (Jompa \& McCook 2002a,b). Similarly, the highly aggressive corals in this study are major coral space-occupiers in the Caribbean. The 3 most aggressive genera in this study, Montastraea, Diploria and Colpophyllia together averaged $69 \%( \pm 6 \mathrm{SE}$ ) and $32 \%$ of live coral cover $( \pm 10 \mathrm{SE})$ at 6 and $20 \mathrm{~m}$ depths respectively in Curaçao ( $\mathrm{n}=6$ sites, M. M. Nugues unpubl. data). Consequently, the use of MFs may be a common and widespread mechanism of interaction between corals and macroalgae.

A great deal more research is needed to forecast the consequences of this mechanism in coral-algal phaseshifts. The use of MFs by certain coral species against macroalgae may not guarantee their long-term survival on reefs where macroalgae abound. Nevertheless, this defensive mechanism could play an important role in preventing or delaying coral-algal phase-shifts. This study suggests that coral-algal competition involves complex mechanisms that are unlikely to lead to a simple hierarchical structure. The existence of many competitive mechanisms has resulted in low rates of competitive displacement in cryptic and open coral reef communities (Jackson \& Buss 1975, Bak et al. 1982, Lang \& Chornesky 1990). Although competitive overgrowth of corals by algae has been advocated as a major cause of coral reef degradation (Miller 1998, McCook 1999), this process may be slow or absent if corals have the ability to prevent algal overgrowth.

Acknowledgements. We thank the staff of the CARMABI research institute for their support of the project, with special thanks to W. Bakhuis, A. Debrot, L. Pors, B. Leysner and C. Winterdaal. We are indebted to G. Nieuwland, J. Bakker and D. Nugues for considerable help with fieldwork, to E. Drew for helpful suggestions on the sampling of Halimeda opuntia, and to J. van der Meer for help with the statistics. This work was supported by a Marie-Curie postdoctoral fellowship (EVK3-CT-2001-50007) to M.M.N. under the Environment and Sustainable Development programme of the European Community.

\section{LITERATURE CITED}

Aronson RB, Precht WF (2000) Herbivory and algal dynamics on the coral reef at Discovery Bay, Jamaica. Limnol Oceanogr 45:251-255

Bak RPM (1977) Coral reefs and their zonation in the Netherlands Antilles. Stud Geol Am Assoc Pet Geol 4:3-16

Bak RPM, Elgershuizen JHBW (1976) Patterns of oil-sediment rejection in corals. Mar Biol 37:105-113

Bak RPM, Termaat RM, Dekker R (1982) Complexity of coral interactions: influence of time, location of interaction and epifauna. Mar Biol 69:215-222

Borowitzka MA, Larkum AWD (1976) Calcification in the green alga Halimeda. IV. The action of metabolic inhibitors on photosynthesis and calcification. J Exp Bot 27:894-907

Burnett JW, Bloom D, Imafuku S, Houck H, Vanucci S, Aurelian L, Kokelj F (1995) Recent advances in cnidarian venom research 1991-95; clinical, chemical and immunological aspects. In: Den Hartog JC (ed) Proc 6th Int Conf Coelenterate Biol, Leiden, National Natuurhistorik Museum, p 77-84

Carpenter RC (1990) Mass mortality of Diadema antillarum I. Long-term effects on sea urchin population dynamics and coral reef algal communities. Mar Biol 104:67-77

Chadwick NE (1987) Interspecific aggressive behavior of the corallimorpharian Corynactis californica (Cnidaria: Anthozoa): effects on sympatric corals and sea anemones. Biol Bull (Woods Hole) 173:110-125

Chornesky EA (1983) Induced development of sweeper tentacles on the reef coral Agaricia agaricites: a response to direct competition. Biol Bull (Woods Hole) 165:569-581

Connell JH (1973) Population ecology of reef-building corals. In: Jones OA, Endean R (eds) Biology and geology of coral reefs, Vol II: Biology 1. Academic Press, New York, p 205-245

Den Hartog JC (1977) The marginal tentacles of Rhodactis sanctithomae (Corallimorpharia) and the sweeper tentacles of Montastrea cavernosa (Scleractinia): their cnidom and possible function. Proc 3rd Int Coral Reef Symp 1:463-469

De Ruyter van Steveninck ED, van Mulekom LL, Breeman AM (1988) Growth inhibition of Lobophora variegata (Lamouroux) Womersley by scleractinian corals. J Exp Mar Biol Ecol 115:169-178

Diaz-Pulido G, Diaz JM (1997) Algal assemblages in lagoonal reefs of Caribbean oceanic atolls. Proc 8th Int Coral Reef Symp 1:827-832

Drew EA, Abel KM (1990) Studies on Halimeda. III. A daily cycle of chloroplast migration within segments. Bot Mar 33:31-45

Duerden JE (1902) West Indian madreporarian polyps. Mem Natl Acad Sci 8:399-597

Edmunds PJ (2002) Long-term dynamics of coral reefs in St. John, US Virgin Islands. Coral Reefs 21:357-367

Grosberg RK (1981) Competitive ability influences habitat choice in marine invertebrates. Nature 290:700-702

Hughes TP (1994) Catastrophes, phase shifts, and large-scale degradation of a Caribbean coral reef. Science 265: $1547-1551$

Hughes TP, Szmant AM, Steneck RS, Carpenter RC, Miller S (1999) Algal blooms on coral reefs: what are the causes? Limnol Oceanogr 44:1583-1586

Jackson JBC, Buss L (1975) Allelopathy and spatial competition among coral reef invertebrates. Proc Natl Acad Sci USA 72:5160-5163

Jompa J, McCook LJ (2002a) Effects of competition and herbivory on interactions between a hard coral and a brown alga. J Exp Mar Biol Ecol 271:25-39 
Jompa J, McCook LJ (2002b) The effects of nutrients and herbivory on competition between a hard coral (Porites cylindrica) and a brown alga (Lobophora variegata). Limnol Oceanogr 47:527-534

Jompa J, McCook LJ (2003a) Contrasting effects of turf algae on corals: massive Porites spp. are unaffected by mixedspecies turfs, but are killed by the red alga Anotrichium tenue. Mar Ecol Prog Ser 258:79-86

Jompa J, McCook LJ (2003b) Coral-algal competition: macroalgae with different properties have different effects on corals. Mar Ecol Prog Ser 258:87-95

Karlson RH (1980) Alternative competitive strategies in a periodically disturbed habitat. Bull Mar Sci 30:894-900

Karlson RH (1999) Dynamics of coral communities. Kluwer, Dordrecht

Koop K, Booth D, Broadbent A, Brodie J and 16 others (2001) ENCORE: the effect of nutrient enrichment on coral reefs. Synthesis of results and conclusions. Mar Pollut Bull 42: 91-120

Lang JC (1973) Interspecific aggression by scleractinian corals. II. Why the race is not only to the swift. Bull Mar Sci 23:260-279

Lang JC, Chornesky EA (1990) Competition between scleractinian reef corals - a review of mechanisms and effects. In: Dubinsky Z (ed) Ecosystems of the world, Vol 25. Coral Reefs. Elsevier, Amsterdam, p 209-252

Lapointe BE (1999) Simultaneous top-down and bottom-up forces control macroalgal blooms on coral reefs. Limnol Oceanogr 44:1586-1592

Littler DS, Littler MM (2000) Caribbean reef plants. Offshore Graphics, Washington, DC

Logan A (1984) Interspecific aggression in hermatypic corals from Bermuda. Coral Reefs 3:131-138

McClanahan TR, Muthiga NA (1998) An ecological shift among patch reefs of the Glovers Reef Atoll, Belize over 25 years. Environ Conserv 25:122-130

McClanahan TR, Aronson RB, Pretch WF, Muthiga NA (1999) Fleshy algae dominate remote coral reefs of Belize. Coral Reefs 18:61-62

McCook LJ (1999) Macroalgae, nutrients and phase shifts on coral reefs: scientific issues and management consequences for the Great Barrier Reef. Coral Reefs 18: $357-367$

McCook LJ (2001) Competition between corals and algal turfs along a gradient of terrestrial influence in the nearshore central Great Barrier Reef. Coral Reefs 19:419-425

McCook LJ, Jompa J, Diaz-Pulido G (2001) Competition between corals and algae on coral reefs: a review of evidence and mechanisms. Coral Reefs 19:400-417

Editorial responsibility: Otto Kinne (Editor),

Oldendorf/Luhe, Germany
Miller MW (1998) Coral/seaweed competition and the control of reef community structure within and between latitudes. Oceanogr Mar Biol Annu Rev 36:65-96

Miller MW, Hay ME, Miller SL, Malone D, Sotka EE, Szmant AM (1999) Effects of nutrients versus herbivores on reef algae: a new method for manipulating nutrients on coral reefs. Limnol Oceanogr 44:1847-1861

Muscatine L (1973) Nutrition of corals. In: Jones OA, Endean R (eds) Biology and geology of coral reefs, Vol II: Biology 1. Academic Press, New York, p 77-115

Ostrander GK, Armstrong KM, Knobbe ET, Gerace D, Scully EP (2000) Rapid transition in the structure of a coral reef community: the effects of coral bleaching and physical disturbance. Proc Natl Acad Sci USA 97:5297-5302

Price WS (1973) Aspects of feeding behaviour of West Indian reef corals. MSc thesis, McGill University, Montreal

Richardson CA, Dustan P, Lang JC (1979) Maintenance of living space by sweeper tentacles of Montastrea cavernosa, a Caribbean reef coral. Mar Biol 55:181-186

Riegl B (1995) Effects of sand deposition on scleractinian and alcyonacean corals. Mar Biol 121:517-526

River GF, Edmunds P (2001) Mechanism of interactions between macroalgae and scleractinian on a coral reef in Jamaica. J Exp Mar Biol Ecol 261:159-172

Shulman MJ, Robertson DR (1996) Changes in the coral reefs of San Blas, Caribbean Panama-1983 to 1990. Coral Reefs 15:231-236

Sokal RR, Rohlf FJ (1995) Biometry. The principles and practice of statistics in biological research, 3rd edn. WH Freeman, New York

Stark LM, Almodova L, Krauss RW (1969) Factors affecting the rate of calcification in Halimeda opuntia (L.) Lamouroux and Halimeda discoidea Decaisne. J Phycol 5:305-312

Szmant AM (2002) Nutrient enrichment on coral reefs: is it a major cause of coral reef decline? Estuaries 25:743-766

Van Duyl FC (1985) Atlas of the living reefs of Curaçao and Bonaire, Netherlands Antilles. Publ Found Sci Res Caribb Reg 117:1-13

Van-Praet M (1985) Nutrition of sea anemones. Adv Mar Biol 22:65-99

Wahle CM (1980) Detection, pursuit, and overgrowth of tropical gorgonians by milleporid hydrocorals: Perseus and Medusa revisited. Science 209:689-691

Williams ID, Polunin NVC (2001) Large-scale associations between macroalgal cover and grazer biomass on middepth reefs in the Caribbean. Coral Reefs 19:358-366

Yonge CM (1930) Studies on the physiology of corals. I. Feeding mechanisms and food. Sci Rep Gt Barrier Reef Exped $1: 13-57$

Submitted: January 14, 2004; Accepted: April 20, 2004

Proofs received from author(s): August 30, 2004 